\title{
SCIENCE AND TECHNOLOGICAL ASPECTS IN RELIGIOUS RITUALS IN THE WOMEN FARMERS GROUP OF JEMPIRING KABUPATEN BADUNG, BALI, INDONESIA
}

\author{
Ni Wayan Suryathi", Made Antara, Nengah Bawa Atmaja, and Wayan Windia \\ Study Program of Doctoral Program of Agricultural Science, University of Udayana, Denpasar, Bali, Indonesia \\ *Corresponding author: suryathiniwayan@yahoo.com
}

\begin{abstract}
This study aims to analyse the science and technological values in religious rituals in the women farmers group of Jempiring Kabupaten Badung. The data was analysed qualitatively. The results show: science and technological values in religious rituals which are implemented through Tri Hita Karana which are harmonious relationship with God, harmonious relationship with other people, and harmonious relationship with the environment, it is evident from Banten Pejati that is complete with segehan Agung which is given on piodalan at Pura Melanting. Ans it is also followed by pemerastitaan and pelukatan rituals for the group's members. Daksina in Banten Pejati is the symbol of God's palace. This symbol provides a scientific-psychotheological effect that makes the minds of the people moored in the presence of a metaphysical god in the support of physical daksina. This value is also found in the sound of kul-kul, genta, gamelan, kidung and mantra during rituals. A harmonious relationship with other people is also seen from the behavior of good and honest members with a basis of menyame braya.
\end{abstract}

Keywords: Science and technological aspects, religious rituals, the women farmers group of Jempiring

\section{INTRODUCTION}

Indonesian society is a pluralistic society, one of the effects of pluralism is that there are various religious rituals carried out and preserved by each of its supporters. Religious rituals in ethnic cultures are usually the most visible cultural elements (Trisna, 2017). According to Rothenbuhler (1998), rituals are always identified with habits or routines. Couldry (2005) understands ritual as a habitual action, formal action and also contains transcendental values. Ritual is a way or method that makes a custom or habit become holy (Donder, 2017). Rituals are always symbolic behavior in social situations.
Therefore ritual is always a way to convey something (Yermia, 2011).

The success of the Jempiring Women Farmers Group in Kabupaten Badung is still ongoing, not only due to capital factors, the availability of production facilities, and the involvement of farmers in farmer groups (Malta, 2014), a human resource factor (Mukson, et al., 2009), organizational culture, communication, product quality (Adji, 2015) but also due to cultural capital, namely local wisdom (communication with Atmaja, 2014). Local wisdom in foreign languages is often conceptualized as local wisdom, local knowledge or local genious (Siswandi et al, 
2011). According to Wagiran (2012) local wisdom can also be interpreted as a thought about life. Local wisdom is defined as cultural knowledge possessed by a particular society that includes a number of cultural knowledge relating to models of sustainable management and use of natural resources (Aulia and Dharmawan, 2010).

One of the local wisdoms of Hindus in Bali that promotes harmonization of relationships is tri hita karana which is derived from the holy book of the Baghawad Gita of Hindu religion. Tri hita Karana is a concept of harmonization of relationships that is always guarded by the Hindu community in Bali. The concept of tri hita karana that developed in Bali is a cultural concept rooted in religious teachings (Riana, 2011). It is through this religion and belief that humans make connections with the unseen (God) who are seen as having an influence in human life (Hasbullah, dan Awang,2017). Tri Hita Karana values are a concept that becomes the philosophy of the balance of life of the Hindu community in Bali including the harmonious relationship between humans and God (parhyangan), between humans and humans (pawongan), and between humans and the environment (palemahan) (Pertiwi and Ludigdo, 2013). The concept of tri hita karana is in line with the opinion of Tenaya (2007) which states that the concept of life must always prioritize the principles of togetherness, harmony and balance between economic goals, environmental and cultural preservation, aesthetics and spiritual.

The Women Farmer Group of Jempiring of Kabupaten Badung in its activities to advance the business is always based on the spirit of Tri Hita Karana. The implementation of tri hita karana to maintain a harmonious relationship with God is carried out through offering activities in the form of yadnya, always maintaining the spirit of celebrating my brotherhood in an effort to maintain a harmonious relationship with fellow human beings, while maintaining a harmonious relationship with the natural environment that is, by maintaining the cleanliness of the business environment, as well as carrying out yadnya activities (pecaruan) for nyomia butha kala.

\section{MATERIALS AND METHODS}

This research was conducted at the Jempiring Women Farmers Group in Kabupaten Badung. The selection of research site was done intentionally (purposive) (Antara, 2010): namely a deliberate research site determination technique based on various considerations. Sources of data in this study consisted of: 1) primary data, namely data obtained by direct interviews with respondents, namely with the group leader; 2) secondary data is obtained by analyzing and conducting literature review on various 
literatures, journals, books, papers and information from the internet related to research topics (Aulia and Dharmawan, 2010) The type of data used in this study is qualitative data, namely data in the form of descriptions or information about the implementation of tri hita karana of the Women Farmers Group of Jempiring in Kabupaten Badung. Data collection techniques are carried out through interviews, observation (data collection through going directly to the location of the study, and documentation study namely document tracking is carried out as reinforcement of data that cannot be completed from participant observations and in-depth interviews.

Data analysis used in this study is qualitative data analysis, namely as a research procedure that produces descriptive data in the form of written or oral words from people or observable behavior (Moleong, 2007). Descriptive can be interpreted as a problem solving procedure that is investigated by describing the state of the subject / object of research based on the facts that appear or as they are (Nawawi, 1995). Qualitative data is present in the form of diaries in the form of observations, interviews, and quotations from various documents (Sitorus, 1998). The data analysis stages are as follows.

1. Data reduction is writing or typing data and deciphering data and reporting in detail (Kaelan, 2012). The data obtained needs to be reduced (added or removed unnecessary data or considered less important).

2. Data presentation is a set of structured information that gives the possibility of drawing conclusions and taking action in the form of narrative text.

3. Conclusions drawn in this case include verification of conclusions by: rethinking during writing, reviewing field notes, reviewing and exchanging ideas between peers and discussing with academic advisers (Sitorus, 1998).

Hendropuspito (1983) states that sociological approaches to phenomena in religious communities can be understood empirically to achieve social law in general. Using a sociological approach means understanding religion not only as a theologically-dogmatic teaching, but looking at the religious practices that exist in religious communities themselves both those represented by institutions and their daily practices. The reason for choosing this sociological approach is to get a mutually correlated understanding between religious teachings according to the Women Farmers Group of Jempiring in Kabupaten Badung with the behavior of members in the middle of their social space. 


\section{RESULTS AND DISCUSSION}

KWT Jempiring Kabupaten Badung runs business activities based on the local wisdom of tri hita karana. Tri Hita Karana is a cultural system, where this system has three sub-systems namely mindset (concept / value), social, and artifact / material
(Koentjaraningrat, 1993 as cited in Windia dan Ratna (2007). The business system of KWT Jempiring in Kabupaten Badung which is based on tri hita karana is expected to be elaborated like the form of a business system as shown in Table 1 below.

Table 1. The Implementation of Tri Hita Karana in Business Activities of KWT Jempiring Kabupaten Badung

$\begin{array}{lll}\text { No } & \text { THK as a Base of } & \text { Implementation of THK } \\ & \text { Business System } & \end{array}$

1 Gatra Parhyangan a. Business activities are activities blessed by God.

b. Business activities at KWT Jempiring in Kabupaten Badung highly uphold the values of harmony and togetherness.

c. KWT Jempiring Kabupaten Badung has very clear business goals.

2 Gatra Pawongan

a. The KWT Jempiring Organizational Structure is very flexible, can be adapted to existing situations and conditions.

b. Harmonious relationships are always maintained among administrators, members, and instructors from the government.

c. Member rights are given openly.

3 Gatra Palemahan

a. Padmasana (Pura Melanting) as a place for prayer together.

b. Every day offer banten for nyomia butha kala.

The table above shows that the with their environment, which can be application of tri hita karana of KWT explained as follows:

Jempiring in Kabupaten Badung is contained in each of the tri hita karana elements, namely parhyangan, pawongan, and palemahan. Middya (2015) states that tri hita karana is a set of rules and regulations that govern human relations with their God, human relations with other humans, and regulate human relations

\section{a. Theological, Sociological and Ecological Harmonization is Well Preserved}

The Jempiring's Women Farmers Group in Kabupaten Badung in maintaining the continuity of its group is always guided by the ancestral heritage, especially in the implementation of ceremonies / rituals in the 
tri hita karana philosophy. Rituals have divine values or theological meanings. The theological meaning is implicit and explicit as stated in the Hindu sacred text. The ritual or yadnya is the source of the law of karma (the law of cause and effect) to be a source of religious activity (Donder, 2017). Rituals by the majority of Balinese Hindus are equated with means of banten which is a sacred sacrifice in the form of sesajen consisting of various kinds of materials both made from plants and animals. Sesajen is offerings intended for the existence of ancestral spirits because in this case it is considered favored by him, and placed in a certain place (Trisna, 2017). Rituals in the form of banten/sesajen are real symbols of the expressions and attitudes of Balinese Hindus to God, as a token of gratitude, gratitude to God in the same way as God does with His various manifestations (Donder, 2017).

Ritual banten with various elements of material is the easiest way done by humanity. Because it has a real form, it can be seen with the eyes, therefore it is effectively carried out by people who are still lay in the spiritual. It is spiritual science which deals with the methodology and technology of the soul which allows the soul to be able to recognize itself and return to its true identity (Donder 2017). The habit of carrying out religious rituals received from the predecessors is a religious belief as a mythological formulated as follows: 1) In order for a society to live directly, there must be a sentiment in the soul and body that stimulates them to behave according to community needs. 2) Each element in a social system and every symptom or object has an effect on community solidarity, becoming the main orientation of community sentiment. 3) That sentiment is generated in the minds of individual citizens as a result of the influence of the lives of their people. 4) Ceremonial customs are a vehicle with what sentiments can be expressed collectively and repeatedly at certain times. 5) Collective expression of sentiments that maintains the intensity of that sentiment in the soul of the community, and aims to continue to the next generations (Pandupitoyo, 2015).

Hindus to maintain harmonious relations based on the teachings of Hinduism which in the activities of the Religious Ceremony are based on the Panca Yadnya. The Panca Yadnya Ceremony, which is the five sincere sacrifices which include: Dewa Yadnya is a sincere sacrifice to God and all of his manifestations, Rsi Yadnya is an offering to the Rsi, Pitra Yadnya is a sacred offering directed to holy spirits and ancestors, Manusa Yadnya is a spiritual cleansing against someone from the womb to the end of his life, Bhuta Yadnya is a sacred sacrifice or offering to the Bhuta Kala and the forces of nature (Sutriani, 2015). 
In the activities of maintaining the continuity of the group's business, the Jempiring's Women Farmers Group in Kabupaten Badung constantly strives to maintain a harmonious relationship through the implementation of tri hita karana. One such implementation is the harmonious relationship with God through the offering in the form of yadnya (by offering / delivering offerings) (element of Parahyangan). The series of offering ceremonies carried out by the Jempiring's Women Farmers Group in Kabupaten Badung are as follows:

1) Nitya yadnya

The Nitya yadnya is the yadnya carried out by the Jempiring's Women Farmers Group in Kabupaten Badung every day in the form of Yadnya sesa. Yadnya sesa, often referred to as masaiban or ngejot, is the yad which is presented to the face of God along with all its manifestations after cooking the snacks to be sold, after cooking rice to be eaten.

2) Jnana yadnya

Jnana yadnya, is yadnya in the form of knowledge. The implementation is done with the process of learning correctly informally. This is implemented by the Jempiring's Women Farmers Group of Kabupaten Badung by conducting training in making snacks, namely making snacks bolu and mangkok. Through education and training, the insight of group members will be broader and more creative to develop their business.

3) Naimittika yadnya

Naimittika yadnya is yadnya done regularly and at certain times that have been scheduled. The implementation uses a certain calculation based on the calculation as follows.

a. Based on the calculation of wara. The calculation of wara is a calculation that uses a combination of tri wara and para wara. Example: Kajeng kliwon.

b. Using a combination of sapta wara and panca wara. Example: Buda wage, Buda kliwon, Anggara kasih and others.

c. Based on Wuku's calculation, the implementation of yad is done by taking into account pawukon like : Galungan, Pagerwesi, Saraswati, Kuningan.

d. Based on the calculation of Sasih. Example: Puranama, Tilem, Nyepi, Siwaratri.

The Jempiring's Women Farmer Group of Kabupaten Badung implements its Naimittika Yadnya through incidental prayers (periodically) every month. In May 2015, where there were the most holy days among the other months, as many as 12 Hindu holy days. Those holy days are Saraswati, Banyupinaruh, Purnama Destha, Some Ribek, hari Sabuh Emas, Pagerwesi, Kajeng Kliwon 
uwudan, Tumpek Landep, Redite Umanis Ukir (Pujawali Hyang Guru di Kemulan), Tilem Destha, Budha Wage, and Sukra Umanis (Rahinan Betare Sri). The group also carries out offerings and prayers during the odalan day at Melanting Temple together.

The ritual at Melanting Temple is a form of gratitude because the group members have been given health and fortune from the market where they sell their processed products. With confidence in the greatness of God, the benefits gained will be able to provide benefits in improving family welfare (jagadita family). At this time the ceremony of pelukatan and pewintenan is also conducted which aims to cleanse all members of the group (pawongan), as well as the mecaru ceremony which is a ceremony intended for nyomia butha kala which means as an expression of gratitude to the natural environment that has given happiness to humans, so that no disasters occur that disrupt activities during the ceremony (palemahan).
The sesajen offered at Melanting Temple are prayer offerings, as well as various other offerings offered at each pelinggih. Given that Hinduism is a religion filled with symbols made of physical objects. Then the daksina contained in the prayer is the symbol of the palace of God. The use of daksina as a symbol of the god's palace provides a scientific-psycho-theological effect that makes Hindus mind moored in the presence of a metaphysical god in the physical support of daksina. This proves that daksina as an object that was originally a propan object can also represent something sacred after its position is changed to sacral through the process of sacralization. Through daksina which functions to control thoughts that are less concentrated to imagine the presence of God, this can be seen as having scientifictechnological functions. Therefore the presence of daksina in every Hindu ritual becomes absolute, because besides having theological meaning it also has scientifictechnological meaning (Donder, 2017).

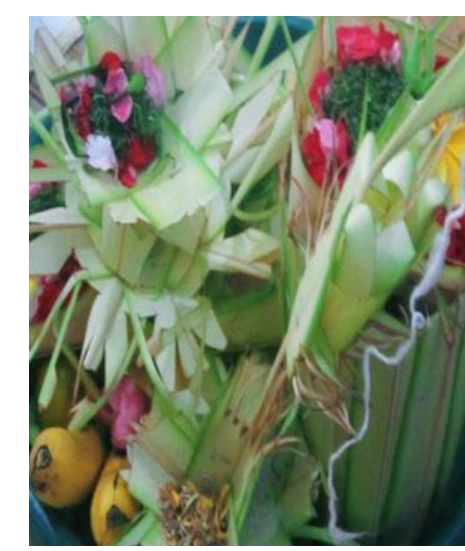


Fig. 1. Banten (offering) and Pejati during rahinan at Melanting Temple

(Source: Research Document, 2015)

Religious rituals in an effort to so as not to interfere with the lives of maintain a harmonious relationship with humanity and is even expected to help nature and the environment are through humanity. The forms of the Bhuta Yadnya ceremony of Butha Yadnya. A sacred offering ceremony include Segehan, Caru to Tawur. ceremony that is sincere in the face of natural Humans live on this earth requires peace, elements (maintaining the welfare of nature). coolness, peace and pleasure to be born and This ceremony is more directed at the goals mindful. Humans live in nature and from for nyomia Bhuta Kala or various negative natural products. This is what underlies the forces that are seen as being able to disrupt human life. Bhuta Yadnya essentially aims to harmonious relationship between humans and realize Bhuta Kala to become Bhuta Hita. Bhuta Hita means prospering and preserving the natural environment (Sarwaprani). The Bhuta Yadnya ceremony is more inclined to the universe. To maintain balance with nature, Hindus carry out tumpek uye (tumpek kandang), which aims to preserve animal life, and implement tumpek warige (tumpek bubuh) to conserve plants. (Tarna, 2014).

listen or reconcile / neutralize negative forces
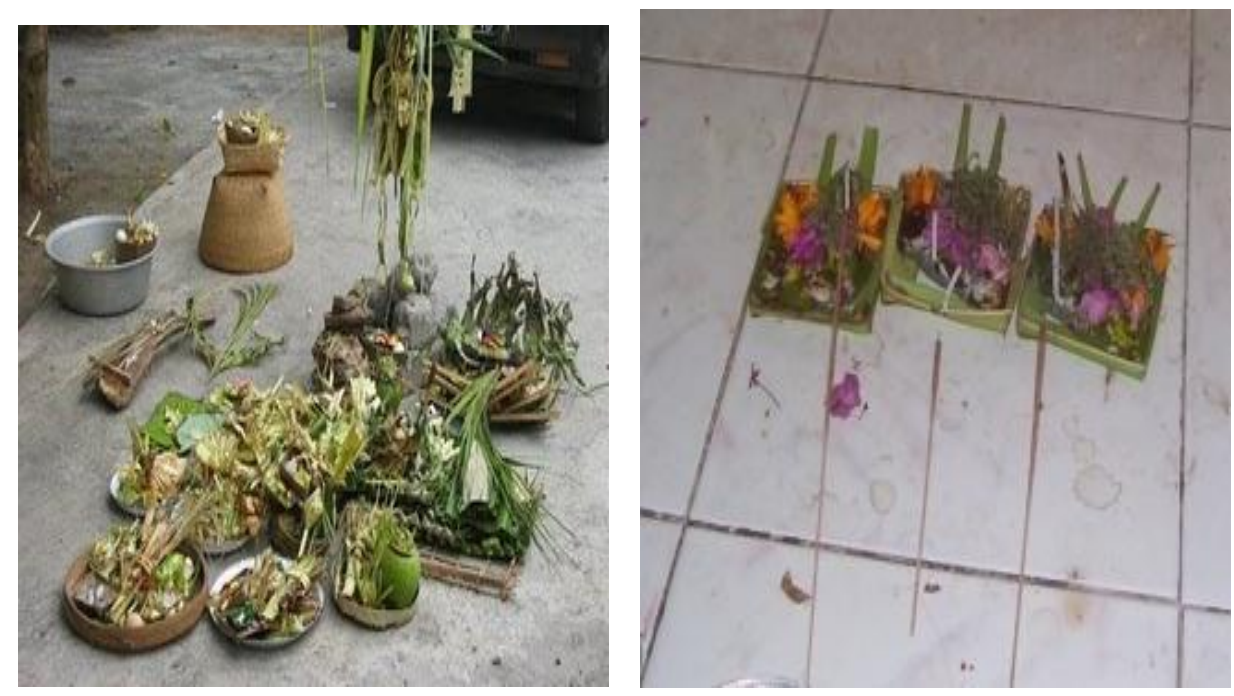

Fig. 2. Banten Pecaruan and Segehan

Source: Anonymous (2015)

Every ritual performed by the group, both the rituals involving parhyangan (to God), pawongan (for harmony in human life) and palemehan (for the survival of plants and animals), are led by people who have competence in the field of religion (Pedande 
in each Temple). Rituals are carried out with various religious hymns, with sounds of kulkul, gamelan, kidung, genta, mantra, (panca nada). The genta and mantra sounds are used by Pinandita and Pandita together as the final stage method in the process of reducing the frequency of the mind waves so that the mind focuses on purity and silence in prayer. Without realizing that Panca Nada inherited by the ancestors is a legacy that contains elements of high-level science and technology that transform the values of physical awareness towards metaphysical awareness. Therefore the preservation of Panca Nada is not solely dogma or apology, but for rational, scientific and technological reasons (Donder, 2017).

Besides that, the concept of Palemahan is also applied by way of responsible for the preservation of nature. This responsibility is carried out by the community in the territory. Palemahan at the regional level covers the territory of Bali Province. At the traditional village level includes "asengken" bale agung. At the family level includes housing estates. A clear example of the application of this concept is the existence of awig-awig (rules) in a village that prohibits illegal logging (Agus, 2011). In line with Suharman's (1987) study "The Samurai and Bushido Teachings in the Character Education Perspective". Bushido cannot be separated from the attitude of the
Samurai in carrying out his beliefs. Generally, the Samurai adhere to and practice Zen Buddhist beliefs, based on their deepening an attitude arises to seek harmony with the universe, especially with the natural environment. This is in line with one of the implementations of Tri Hita Karana namely a harmonious relationship that is always maintained with the natural environment.

\section{b. Ritual Facilities as Psycho-technology}

Rituals in Hinduism have a function as a medium to link Hindus to metaphysics, so Hindu rituals can be declared to have scientific values. This means that the human mind is limited to understanding, especially realizing the metaphysical, but in Hindu ritual is used as a medium of learning to Hindus evolutionarily able to capture the metaphysical meanings behind the forms of physical ritual means. The ritual facilities function very significantly in creating the nuances of the human mind. Thus it can be stated that the means of ritual has a psychological effect on its users. Therefore, it can be stated also that there is no doctrinal and apologetic ritual in Hinduism. On the contrary, Hindu rituals are nothing but tangible manifestations of spiritual science and technology that can reduce the waves of thought (Donder, 2017).

\section{c. Harmonious Relations with Fellow Group Members}


A harmonious relationship with fellow human beings is called pawongan. In a narrow sense, pawongan is a group of people who live in one area of society. It is a concept that wants harmony between humans and their fellow human beings. The relationship between humans and other creatures is the relationship between family members, society, between children, husband and wife and others (Agus, 2011).

Harmonious relationships to fellow group members are carried out by religious rituals, namely by the ceremony of Pelukatan and Pewintenan. While the harmonious relationship with fellow human beings in daily life in group business activities is carried out by maintaining perseverance in business, maintaining honesty in returning all debts, because of fear of karmaphala law, maintaining cooperation with fellow members for the progress of the group, and every decision is always carried out on the basis of joint decisions so that the dignity of the organization can still be maintained which is detailed as described below.

1) The leader and members are complementary in upholding the organization and handling problems

The Jempiring's Women Farmer Group of Kabupaten Badung as a social creature will naturally always need a fabric of cooperation with fellow human beings, cannot be separated from the community and no one is able to stand alone doing all activities to meet their needs. Likewise in the group business activities each group member will always need the presence and role of others. Not an entrepreneur or entrepreneur can succeed because of his own work or business. Therefore, one of the keys to business success is success in business cooperation. Collaboration basically shows that there is agreement between two people or more that is mutually beneficial (complementary) (Suwardi, 2014).

The group leader on the other hand must also be able to give a big influence and can motivate its members to work, in order to be more optimal in their performance. Effective leaders must be able to provide direction, evaluation, and correction of the efforts made by members in achieving organizational goals, because the organization has two principles, namely having to survive and develop (Graciaet al., 2017). Individuals and groups must create working relationships that support each other, towards achieving organizational goals. Although interdependent relationships can also give birth to conflict, but because the organization has an interest or purpose for business progress, the leader will be maximal in carrying out his duties if there is good cooperation with subordinates (employees) who always interact and help him (Gibson and James, 1997). 
2) Decision making by deliberation to advance group organizations

Decision making is a series of activities carried out to solve the problem at hand. Decision making can be interpreted as the essence of the administrative process. In essence, decision making is a systematic approach to the nature of a problem, gathering facts and data, determining the maturity of the alternatives faced and taking actions that according to calculations are the most appropriate actions. Decision-making methods can be done individually, in groups, teams or committees, councils, commissions, referendums, submitting written proposals and so on (Murtiningsih, and Bukman, 2017). For a leader, decision making is one of the functions that cannot be avoided, because without decisions and policies the leadership function cannot be implemented and the management function cannot work to realize organizational goals (Marzuki, 2015). Decisions are manifestations of leadership authority that are highly expected by subordinates, because without decision making, all subordinate activities become uncertain. Uncertainty about a decision can lead to weak leadership functions towards organizational stability (Dermawan, 2006).

The Jempiring's Women Farmer Group of Kabupaten Badung, as a small organization in the Village, regularly holds meetings every month. In each meeting all actions taken by group members are built based on communication and interaction between individuals. Based on the commitment of all group members to advance the group, then whenever there is a problem, decision making is done in consultation to advance the group that has been formed thus far. In the process of decision making by the group is done by involving all group members. The group leader works with all group members to mobilize their members in completing tasks, responsibilities, authority in making decisions to advance group efforts. The limited knowledge and experience possessed by the group leader did not dampen the leader to work with all members, so that in expressing ideas and ideas to be implemented for the progress of the group's business through routine activities carried out.

3) The dignity of group organizations is maintained

Real dignity cannot be attributed to visible results. There are ethical values that are inherent and cannot be ignored in the process of achieving dignity. This process determines the quality of human nobility. If these values are ignored, then dignity as an effort to achieve the level of nobility can be something that damages values (Juliasih,2014). Therefore, dignity is placed as the main value in life, especially life in the group. In order to maintain the dignity of the group so that they can be trusted by the 
government and the community, each member must strive to maintain good behavior as a group member. In this case it is related to the use of Community Direct Aid (BLM) funds from the Kabupaten Badung Government. The group is always accountable for existence as it is (do not commit lies and fraud related to accountability). Group members are always honest, obedient, loyal, and maintain the dignity of the organization in returning the debts borrowed to group members. All that is done by group members with togetherness and honesty in building a business is always because they want to maintain the dignity of the group they agree on for the continuity of their business.

4) Building network based on menyame braya

The concept of menyama braya has always existed and developed in Bali, but as time went by slowly this concept of branding was eroded. Therefore, it needs to be encouraged again so that harmony in religious life can be fostered properly. It is a union knot in which there is a bond of togetherness and kinship and mutual belonging. It is used as a local wisdom that can be used as a solution in solving various problems in community life in Bali (Asmariani, 2017).

\section{CONCLUSIONS}

Based on the results it can be concluded that the value of science and technology in religious rituals implemented through Tri Hita Karana is primarily a harmonious relationship to God which is demonstrated through rituals in Melanting Temple by using the facilities of Banten Pejati. Daksina contained in Banten Pejati is a symbol of the god's palace which provides a scientific-psycho-theological effect that makes the minds of the people moored in the presence of a metaphysical god, in the support of physical daksina. Psycho-theological scientific values are also found in the sounds of kul-kul, genta, gamelan, kidung and mantra during rituals. Harmonious relationships with fellow group members through the rituals of pemerastitaan and pelukatan. Good cooperation in handling every problem so that the dignity of the group is maintained, all decisions are made with deliberation and networking built on the basis of menyama braya. Harmonious relationships with the natural environment are carried out with pecaruan, or mesegeh rituals, and maintain environmental cleanliness.

\section{REFERENCES}

Adji, P. S. (2015). Pengaruh Budaya Organisasi dan Komunikasi Terhadap Kinerja (Studi Pada Kelompok Tani Sri Mulyo Malang). (serial online), Oktober, [cited 2015 Okt.]. Available from: URL: http://download. Portalgaruda.org/article. phparticle.

Agus. (2011). Tri Hita Karana Dalam Pendidikan di Bali. (serial online), Oktober, [cited 2014 Okt.]. Available from: URL: http:/pande-agus. 
blogspot.com 2011/12/tri-hita-karanadalam-pendidikan-di.html.

Antara, M. (2010). Metodelogi Penelitian Sosial. Denpasar: Program Studi Agribisnis Udayana Denpasar.

Asmariani, R. A. A. (2017). Nilai Kearifan Lokal Menyame Braya Sebagai acuan dalam Mewujudkan kerukunan Antar dan Inter Umat Beragama di Bali. Denpasar: IHDN Denpasar. Seminar Nasional Filsafat, 17 Maret 2017.

Atmaja, B. N. (2014). Komunikasi Pribadi, di Denpasar.

Aulia \& Dharmawan. (2010). Kearifan Lokal Dalam Pengelolaan Sumberdaya Air di Kampung Kuta Local Wisdom of Water Resource Management in Kampung Kuta. Sodality Jurnal Transdisiplin Sosiologi, Komunikasi, dan Ekologi Manusia 4(3), 345-355. ISSN 1978-4333.

Couldry, N. (2005). Media Rituals;

Beyond Functionalism. dalam Media Anthropology. Editor: Eric W. Rothenbuhler dan Mihai Coman. Thousand Oaks: SAGE Publications.

Dermawan, R. (2006). Pengambilan Keputusan. Bandung: Bagian Penerbit Alfabeta.

Donder, I. K. (2017). Unsur-unsur Sain dan Teknologi dalam Ritual Hindu. Surabaya: Wordd Hindu Parisad dan Paramita.

Gibson, \& James, L. (1977). Organisasi: Perilaku, Struktur, Proses. Alih bahasa oleh Adriani. Binarupa Aksara: Jakarta.

Gracia, F. L., Julia T. P., \& Grace J. W. (2017). Pola Komunikasi Pemimpin Organisasi Dalam Meningkatkan Motivasi Kerja Anggota Di LPM (Lembaga Pers Mahasiswa) Inovasi Unsrat. Acta Diurna, 6 (1).

Hasbullah, Toyo, \& Pawi, A. A. A. (2017). Ritual Tolak Bala Pada Masyarakat Melayu (Kajian Pada Masyarakat Petalangan Kecamatan Pangkalan Kuras Kabupaten Pelalawan). Jurnal ushuluddin, $25(1) . \quad$ Doi: 10.24014/jush.v25i1.2742.

Universitas Islam Negeri Sultan Syarif Kasim Riau, Indonesia.

Hendropuspito. (1983). Sosiologi Agama.Yogyakarta: Kanisius.

Kaelan. (2012). Metode Penelitian Kualitatif Interdisipliner Bidang Sosial, Budaya, Filsafat, Seni, Agama, dan Humaniora. Paradigma: Yogyakarta.

Malta. (2014). Faktor-faktor yang Berhubungan dengan Tingkat Kinerja Petani Jagung Di Lahan Gambut: Kasus Petani Jagung di Lahan Gambut di Desa Limbung - Kabupaten Pontianak. Banda Aceh: Universitas Terbuka, UPBJJ-UT Banda Aceh.

Manafe, Y. D. (2011). Komunikasi Ritual pada Budaya Bertani Atoni Pah Meto di Timor-Nusa Tenggara Timur. Universitas Nusa Cendana Kupang. Jurnal Komunikasi, 1(3).

Marzuki. (2015). Pengambilan Keputusan Sekolah Melalui Manajemen Strategik Pada Sekolah Menengah Pertama Negeri 1 Bandar Baru. Pascasarjana Universitas Syiah Kuala. Jurnal Administrasi Pendidikan, 3(1), 135141, ISSN 2302-0180.

Middya, B. (2015). Agama dan Perubahan Sosial (Tinjauan Perspektif Sosiologi Agama). Palembang: Istinbath, 15(14), 35-50.

Mukson, T., Ekowati, Handayani, M., \& Harjanti, D. W. (2009). Faktor-faktor yang Mempengaruhi Kinerja Usaha Ternak Sapi Perah Rakyat di Kecamatan Getasan Kabupaten Semarang. Semarang: Seminar Nasional Kebangkitan Peternakan Semarang 20 Mei 2009. Fakultas Peternakan Uiversitas Diponegoro.

Murtiningsih, \& Bukman, L. (2017). Proses Pengambilan Keputusan Kepala Sekolah Terhadap Peningkatan Kinerja Guru SMP. Palembang: Jurnal Manajemen, Kepemimpinan, dan Supervisi Pendidikan, 2(1), 92-95. 
Moleong, L. J. (2007). Metode Penelitian Kualitatif. PT. Remaja Rosdakarya: Bandung.

Nawawi, H. (1995). Metode Bidang Penelitian Sosial. Gajah Mada University Press: Yogyakarta.

Pandupitoyo, D. (2015). Teori Struktural Fungsional. (serial online), September, [cited 2015 September]. Available from: URL: http://www.scribd. com/ doc/ TeoriStruktural-Fungsional.

Pertiwi, D. A. E., \& Ludigdo, U. (2013). Implementasi Corporate Social Responsibility Berlandaskan Budaya Tri Hita Karana. Universitas Brawijaya Malang. Jurnal Akuntansi Multiparadigma, 4(3), 430-455.

Rothenbuhler, E. W.(1998). Ritual Communication. From Everyday Conversation to Mediated Ceremony. Thousand Oaks. SAGE Publications.

Riana, G. (2011). Dampak Penerapan Kultur Lokal Tri Hita Karana terhadap Orientasi Kewirausahaan dan Orientasi Pasar. Jurnal Teknik Indonestri, 13 (1), 37-44, ISSN 14112485.

Siswadi S, Tukiman, T., \& Hartuti, P. (2011). Kearifan Lokal dalam Melestarikan Mata Air (Studi Kasus di Desa Purwogondo. Kecamatan Boja. Kabupaten Kendal). Jurnal Ilmu Lingkungan, 9(2), 63-68. ISSN 18298907. Semarang: Program Studi Ilmu Lingkungan. Program Pascasarjana Universitas Diponegoro.

Sitorus, F. (1998). Penelitian Kualitatif: Suatu Perkenalan. Bogor: Kelompok Dokumentasi Ilmu Sosial IPB Bogor.

Suharman. (2002). Sejarah Jepang (Awal sampai Feodalisme). Sala Tiga Jawa Tengah: Widya Sari Press.

Sutriani, N. M. (2015). Nilai-Nilai Pendidikan Agama Hindu Dalam Tradisi Magebeg-Gebegan Godel Pada Upacara Bhuta Yadnya Di Desa Pakraman Dharmajati, Desa Tukadmungga, Kecamatan Buleleng,
Kabupaten Buleleng. Denpasar: Program Studi Pendidikan Agama Hindu, Fakultas Pendidikan Agama Dan Seni. Unversitas Hindu Indonesia.

Suwardi. (2014). Bentuk-Bentuk Kerjasama Dalam Kegiatan Usaha. (serial online), Nopember, [cited 2014 Nopember]. Available from: URL: https://suwardi.wordpress.com/2014/1 1/12/ bentuk-kerjasama-dlm-usaha.

Tarna, W. (2014). Implementasi Tri Hita Karana. Sekolah Tinggi Agama Hindu Dharma Nusantara: Jakarta.

Tenaya, G. A. I. (2007). Analisis Falsafah dan Konsep Akuntansi dalam Perspektif Filsafat Kultur Bali Tri Hita Karana dan Kesadaran Internal Lembaga terhadap Hukum Perusahaan. Malang: Tesis Program Pascasarjana Universitas Brawijaya Malang.

Trisna, S. W., \& Soebijantoro. (2017). Upacara Adat Mantu Kucing di Desa Purworejo Kabupaten Pacitan (Makna Simbolis dan Potensinya Sebagai Sumber Pembelajaran Sejarah). Jurnal Agastya, 7(1).

Wagiran. (2012). Pengembangan Karakter Berbasis Kearifan Lokal Hamemayu Hayuning Bawana (Identifikasi Nilainilai Karakter Berbasis Budaya). FT Universitas Negeri Yogyakarta: Yogyakarta.

Yermia, Djefri Manafe. (2011). Komunikasi Ritual pada Budaya Bertani Atoni Pah Meto di Timor-Nusa Tenggara Timur. Universitas Nusa Cendana Kupang. Jurnal Komunikasi, 1 (3). Juli 2011. 